\title{
A Comparison of Ammonium Sulfate and Urea as Tobacco Fertilizers
}

\author{
George Samuels, J. Vélez-Santiago, and M. Manzano ${ }^{1}$
}

\section{INTRODUCTION}

Nitrogen is a very important element in the nutrition of tobacco. In Puerto Rico it generally has been supplied for tobacco in the form of ammonium sulfate. In many of the tobacco-growing areas of the United States nitrogen sources other than ammonium sulfate are favored. Connecticut has recommended organic-nitrogen sources such as cottonseed meal, or mixtures of cottonseed meal with urea and ammonium sulfate $(5)^{2}$, for the production of cigar-wrapper tobacco. Florida found that a combination of nitrogen sources was better than one source alone and obtained highest yields and good quality with a mixture of one-third each of sodium nitrate, urea, and sulfate of ammonia (2). Ammonium nitrate was recommended (4) for burley tobacco in Tennessee.

Earlier tests with nitrogen sources in Puerto Rico (3) showed neither organic sources such as cottonseed meal, nor inorganic sources such as ammonium nitrate, sodium nitrate, or urea superior to ammonium sulfate in producing yields of cigar-filler tobacco. Moreover the yields obtained with urea were definitely inferior to those obtained with ammonium sulfate. Inasmuch as other investigators had reported that urea was equal or superior to ammonium sulfate (1), it was decided to reinvestigate the influence of urea and ammonium sulfate as nitrogen sources for cigar-filler tobacco in Puerto Rico. This investigation did not limit the criteria of performance to yields of cured tobacco only, but the influence of these two nitrogen sources on such factors as price, chemical composition, and smoking performance was also determined.

\section{PROCEDURE}

The experiment was planted at the Gurabo Substation Farm. The soil used was a Mabi clay, with a pH 5.5. This soil is a grayish-brown plastic heavy clay which drains well on sloping land but very poorly on level ground.

The experiment consisted of three treatments: 1, No nitrogen; 2, ammonium sulfate; and 3 , urea. All treatments received 200 pounds each of $\mathrm{P}_{2} \mathrm{O}_{5}$ and $\mathrm{K}_{2} \mathrm{O}$ per acre as superphosphate (20-percent $\mathrm{P}_{2} \mathrm{O}_{5}$ ) and potassium sul-

1 Agronomist, Research Assistant in Agronomy, and Assistant Biochemist, respectively, Agricultural Experiment Station, University of Puerto Rico, Río Piedras, P. R.

2 Italic numbers in parentheses refer to Literature Cited, p. 39. 
fate (50-percent $\mathrm{K}_{2} \mathrm{O}$ ). The nitrogen sources were applied at the rate of 100 pounds of nitrogen per acre.

The plots consisted of 5 rows, 42 inches apart, with 15 tobacco plants 18 inches apart in the row, making a total of 75 plants per plot with an area, $171 / 2$ by $221 / 2$ feet, or about one one-hundred and eleventh of an acre. Seedlings of tobacco variety Virginia 12 were selected for uniformity in size and development, and were carefully transplanted to the experimental plots. All mosaic-infected plants were discarded. Seedlings were replanted, if needed, 10 days after the first planting. The fertilizer was applied 10 days after planting the tobacco seedlings, being placed in small semicircular bands at opposite sides of the plant and then covered with soil.

The experiment was laid out in a randomized-block design of three treatments with four replications. The experiment was planted on January 2, 1958, and harvested during the month of April 1958. The tobacco leaves were picked every 8 to 10 days after the first picking was made. All plants were pinched back (topped) after they were fully grown, to prevent flowering and induce enlargement of the leaves. The tobacco leaves collected from each plot at each picking were properly identified and hung in racks in the tobacco barn for drying. The dried leaves were classified ${ }^{3}$, using the standard grades for Puerto Rican cigar-leaf tobacco (U.S. Type 46), as designated by the Tobacco Division, Agricultural Marketing Service, U. S. Department of Agriculture. The classified air-cured tobacco was then weighed.

The weighed and cured tobacco was fermented and then cigars made from that grown under the various treatments. The fermented stripped tobacco was utilized as cigar-filler and a commercial wrapper-tobacco was used for all treatments in making the cigars.

Cigars were distributed with an appropriate questionnaire to 50 regular cigar smokers to evaluate the smoking qualities of the tobacco from the no-nitrogen, ammonium sulfate, and urea treatments.

\section{RESULTS AND DISCUSSION}

The results of the field experiment with ammonium sulfate and urea as nitrogen sources for tobacco are given in table 1. There was no significant difference in yields of field-cured tobacco fertilized with ammonium sulfate or urea. However, yields diminished about 2 hundredweights where no nitrogen was applied, indicating that there was need for nitrogen fertilizers for tobacco on the Mabi clay at Gurabo.

Yields were generally low, even where nitrogen fertilizers were applied; this was attributable, for the most part, to the lack of rainfall, as earlier experiments in this area $(3)$ have shown.

${ }^{3}$ The authors wish to thank Mr. Rafael J. Gonzalez, Tobacco Division, USDA, for classifying the tobacco. 
Prices paid for tobacco differ, depending on its quality. A high yield per acre of a poor-quality tobacco may not bring the farmer as much money as an average yield of high-quality tobacco. The reported values of the cured tobacco per acre are based not only on the yields, but also take quality into consideration. The prices paid for tobacco of the quality obtained under the different treatments in the experiment are given in table 1. No statistical difference was found that could be attributed to the treatments.

One hundred pounds of nitrogen as ammonium sulfate applied per acre would have brought the farmer $\$ 49.63$ more per acre for his tobacco than where no nitrogen was applied. The differences in estimated incomes attributable to urea and to ammonium sulfate were not significant. It should be remembered that in this experiment, sufficient phosphate and potash were

TABLE 1.-The influence of ammonium sulfate and urea on yields and prices of cured tobacco

\begin{tabular}{l|c|c|c}
\hline \multirow{2}{*}{ Treatmentl } & $\begin{array}{c}\text { Cured tobacco, yield } \\
\text { per acre }\end{array}$ & \multicolumn{2}{|c}{ Cured tobacco } \\
& & Price per acre & Price per pound \\
\hline & Cwt. & Dollars & Cents \\
No nitrogen & 3.60 & 89.97 & 25 \\
Ammonium sulfate & 5.42 & 139.60 & 26 \\
Urea & 5.71 & 155.31 & 27 \\
\hline
\end{tabular}

Least significant differences needed between treatments at the: 5-percent level

1.25

17.36

${ }^{1}$ All treatments received $200 \mathrm{lb}$. each of $\mathrm{P}_{2} \mathrm{O}_{5}$ and $\mathrm{K}_{2} \mathrm{O}$ per acre, and $100 \mathrm{lb}$. each of $\mathrm{N}$ where indicated.

applied, 200 pounds per acre of each, to prevent them from being limiting factors in yields.

To apply 100 pounds of nitrogen per acre required 500 pounds of ammonium sulfate (20-percent $\mathrm{N}$ ) as compared to 218 pounds of urea (46-percent $\mathrm{N})$. Urea costs more than ammonium sulfate, but since it contains more nitrogen, less than half the weight of fertilizer is required. Urea costs 14.5 cents as compared to 13.7 cents for ammonium sulfate, per pound of nitrogen applied. The saving in warehouse space and cost of application from the use of urea might reduce the slight price edge ammonium sulfate has over it for large acreages of tobacco.

Tobacco is grown in Puerto Rico primarily for cigars. Thus the final means of comparison between these two nitrogen sources used would be in the smoking quality of cigars made from tobacco fertilized with them. In table 2 the results are given of smoking trials with cigars made from 
ammonium sulfate- and urea-fertilized tobacco. In general, there was little difference.

Tests in Connecticut have shown that ammonium sulfate fertilization produces a darker ash and a slower burning tobacco than organic-nitrogen sources (5). Such quality factors as irritation, aroma of the smoke, taste, and strength of the cigar are unaffected by nitrogen source.

Chemical analyses showed the urea-treated tobacco contained 4.54 percent total nitrogen as compared to 4.80 percent for ammonium sulfate.

TABLE 2.-Evaluation scores of the smoking characteristics of cigars made from tobacco fertilized with urea and ammonium sulfate

\begin{tabular}{l|c|c|c|c|c|c|c}
\hline & \multicolumn{6}{|c}{ Evaluation scorel for- } \\
\cline { 2 - 8 } Treatment & $\begin{array}{c}\text { Combusti- } \\
\text { bility }\end{array}$ & Irritation & $\begin{array}{c}\text { Aroma of } \\
\text { the smoke }\end{array}$ & $\begin{array}{c}\text { Taste of } \\
\text { the smoke }\end{array}$ & $\begin{array}{c}\text { Strength } \\
\text { of the } \\
\text { smoke }\end{array}$ & Color of ash & Average \\
\cline { 2 - 7 } & 2.7 & 3.7 & 3.3 & 2.7 & 4.0 & 3.0 & 3.2 \\
$\begin{array}{c}\text { No nitro- } \\
\text { gen }\end{array}$ & 3.2 & 3.8 & 4.0 & 3.0 & 4.0 & 3.0 & 3.5 \\
$\begin{array}{c}\text { Ammo- } \\
\text { nium } \\
\text { sulfate }\end{array}$ & 3.7 & 4.0 & 3.9 & 3.0 & 4.0 & 4.4 & 3.8 \\
\hline Urea & & & & & & & \\
\hline
\end{tabular}

1 The various quality factors were scored as follows:

\begin{tabular}{|c|c|c|c|c|c|c|c|}
\hline 6 points & $\begin{array}{r}\text { Burns } \\
\text { well }\end{array}$ & None & Aromatic & - & Strong & White & Good \\
\hline 4 points & $\begin{array}{c}\text { Burns } \\
\text { fair }\end{array}$ & Weak & Plain & $\begin{array}{c}\text { Agree- } \\
\text { able }\end{array}$ & $\begin{array}{c}\text { Me- } \\
\text { dium }\end{array}$ & $\begin{array}{l}\text { Gray- } \\
\text { white }\end{array}$ & $\begin{array}{r}\text { Aver- } \\
\text { age }\end{array}$ \\
\hline 2 points & $\begin{array}{l}\text { Burns } \\
\text { poorly }\end{array}$ & Strong & $\begin{array}{c}\text { Disagree- } \\
\text { able }\end{array}$ & $\begin{array}{l}\text { Disagree- } \\
\text { able }\end{array}$ & Weak & $\begin{array}{c}\text { Grey- } \\
\text { ish- } \\
\text { black }\end{array}$ & Poor \\
\hline
\end{tabular}

The work done by Landrau et al. ( $(3)$ indicated that urea gave significantly ower yields of tobacco than did ammonium sulfate. However, this was not the case in the experiment here reported, for no significant differences existed in yields or quality that could be attributed to nitrogen source. While tobacco yields in general were low in this experiment, similar conditions of poor rainfall and low yields were encountered in the former experiments with urea and ammonium sulfate.

From the evidence at hand, it still appears that ammonium sulfate is quite satisfactory as a nitrogen source for growing cigar-filler tobacco in Puerto Rico. Urea might be used, but it offers no economic advantage at present. 


\section{SUMMARY}

Ammonium sulfate and urea were evaluated as nitrogen sources for growing cigar-filler tobacco in Puerto Rico. The results of an experiment on a Mabi clay at Gurabo were:

1. There were no significant differences in yield between tobacco fertilized with ammonium sulfate and urea.

2. Tobacco grown without nitrogen gave significantly lower yields than that to which nitrogen was applied.

3. The cash value per pound or per acre of cured tobacco did not show any appreciable difference that could be attributed to the two nitrogen sources used.

4. There was little or no differences in the smoking qualities of cigars made from tobacco fertilized with the two nitrogen sources, except for a whiter ash where urea was used.

\section{RESUMEN}

En este trabajo se evalúan el sulfato amónico y la urea como fuentes de nitrógeno para el abonamiento del tabaco en Puerto Rico. Los resultados obtenidos mediante la aplicación de estos elementos fertilizantes a un experimento con tabaco llevado a cabo en un suelo del tipo arcilla Mabí en Gurabo fueron los siguientes:

1. No hubo diferencias significativas al comparar los rendimientos del tabaco abonado con sulfato amónico o con urea.

2. Las parcelas a las cuales no se les aplicó abono nitrogenado en forma alguna produjeron rendimientos más bajos, significativamente, que las que recibieron nitrógeno.

3. El ingreso en efectivo por libra o por acre de tabaco vendido, no señaló diferencia alguna que pudiera proceder de la fuente de nitrógeno usada ya fuera sulfato amónico o urea.

4. La diferencia fué poca o ninguna en lo que se refiere a la calidad del tabaco al fumarse y como resultado de su abonamiento con sulfato amónico o con urea. Sólo se observó que la ceniza de los cigarros hechos con el tabaco abonado con urea resultó más blanca.

\section{IITERATURE CITED}

1. Beaumont, A. B., and Snell, M. E., Nitrogenous Fertilizers for Growing Tobacco, Mass. Agr. Exp. Sta. Bul. 346, 1937.

2. Clark, F., Fertilizer Tests with Flue-Cured Tobacco, Fla. Agr. Exp. Sta. Bul. 512, 1953 ,

3. Lundrau, P., Jr., Samuels, G., Alers-Alers, S., and Gonzdlez-Molina, M., The influence of fertilizers on tobacco yields, J. Ayr. Univ. P. R. 43 (1) 60-08, 1050.

4. Nichols, B. C., Bowman, D. R., and McMurtrey, J. E., Jr., Reaponse of Burley Tobacco to Fertilization, Tenn. Exp. Bta. Bul. 280, 1058.

5. Roo, Henry C., Fertilizing Connootiout Tobacco, Conn, Agr. Dxp. Sta. Bul. 613, 1958. 